\title{
Effects of Different Media on Micropropagation and Rooting of Myrtle (Myrtus communis L.) in In Vitro Conditions Özhan Şimşek ${ }^{1 *}$, Belgin Biçen ${ }^{1}$, Dicle Dönmez ${ }^{2}$, Yıldız Aka Kaçar ${ }^{1,2}$ \\ ${ }^{1}$ Çukurova University, Agriculture Faculty Horticulture Department, Adana, Turkey \\ ${ }^{2}$ Çukurova University, Institute of Natural and Applied Sciences, Biotechnology Department, Adana, Turkey \\ *Corresponding author: ozhan12@gmail.com
}

\begin{abstract}
Myrtle (Myrtus communis L.) is a small tree shrub of the family Myrtace, grown naturally of the Mediterranean area. Myrtle is very important as an antiseptic, anti-inflammatory and hypoglycemic agent. Turkey has great genetic resources for myrtle. Propagation of myrtle genotypes is significant issue. Plant tissue culture techniques offer fast and reliable micropropagation for many plant species. Different media content could be used for micropropagation in in vitro condition. The aim of the present study is to determinate of effects of different media on micropropagation and rooting in myrtle. For this purpose, Murashige and Skoog (MS), Rugini Olive Medium (OM) and Woody Plant Medium (WPM) media were used for micropropagation and rooting experiments. All media were supplemented with 1 mg $l^{-1}$ BA for micropropagation, $1 \mathrm{mg} \mathrm{l}^{-1}$ IBA for rooting. The rate of micropropagation and plant length, rooting rate, numbers of root and root length were determined. Rooted with well-developed shoots transferred to plastic pots containing autoclaved peat and perlite $(1: 1, v / v)$. The potted plants were placed in a greenhouse. Acclimatized plants were compared after eight weeks. Means were separated by analysis of variance and the LSD test was performed to examine significant differences. Based on the result, the best medium was detected WPM on micropropagation rate (6.75 per plant), and then MS (4.20 per plant), OM (3.70 per plant). According to rooting data the highest rooting rate was calculated in WPM with 100\%, rooting rate in OM and MS media was detected $70 \%$ and $50 \%$, respectively.
\end{abstract}

Key Words - In vitro, plant tissue culture, $M S, B A, I B A$.

\section{INTRODUCTION}

Myrtus communis L., commonly named Myrtle, is an aromatic shrub of the Myrtaceae family, widespread all around the Mediterranean basin [1].

Myrtle generally grows in the areas with an altitude of 500-600 m above the sea level, especially in pine forests and riversides in the Taurus Mountains of Turkey. Myrtle is also named as "hambeles", "mersin" or "murt" in Turkish [2]. It can be grown successfully in soils under hot, arid environments. Besides the consumption of its fruits, myrtle, an aromatic woody species, is also utilized for ornamental purposes and for the production of antimicrobial compounds. This species has genotypes with bluish-black or yellowish-white colored fruits [3].

M. communis has a long history of use as food preservative and in traditional medicine [1]. The aromatic biochemical compounds isolated from myrtle are used for anti-genotoxic, anti-mutagenic, antiseptic, anti-inflammatory purposes and culinary purposes, such as for the flavoring of sauces, confectionery, and beverages $[4,5,6,7]$

Micropropagation is one of the most important applications of plant tissue culture. It provides numerous advantages over conventional propagation like mass production of true-to-type and disease-free plants of elite species in highly speedy manner irrespective of the season requiring smaller space and tissue source. Therefore, it provides a reliable technique for in vitro conservation of various rare, endangered and threatened germplasm. Micropropagation protocols have been standardized for commercial production of many important medicinal and horticultural crops [8]

Myrtle is known as among recalcitrant species. Therefore many researcher study in in vitro micropropagation and rooting of myrtle. The effects of indole-3-butyric acid (IBA) and activated charcoal (AC) concentrations for in vitro rooting in Myrtle were investigated by Aka Kacar [9]. Şan et al. [6] investigated effects of different concentrations of thidiazuron (TDZ), 6benzylaminopurine (BAP) and naphthalene acetic acid (NAA) on shoot formation and the effect of activated charcoal on rooting for myrtle clone 'Aşı Mersin'. Rezaee and Kamali [10] studied on effect of different media (MS and Woody Plant Medium-WPM) of myrtle micropropagation and rooting in in vitro conditions. Scarpa et al. [11] evaluated the influence of 
two IAA concentrations $\left(0.5 \mathrm{mg} \mathrm{l}^{-1}\right.$ and $\left.1 \mathrm{mg} \mathrm{l}^{-1}\right)$ and different medium for root induction in myrtle. Hatzilazarou et al. [12] investigated rooting capability of two $M$. communis clones.

Different plant tissue culture media could be used for routine micropropagation and rooting in in vitro conditions. Several species may be different responses on different media content in in vitro. The aim of this study is determined of effect of different plant tissue culture media in in vitro propagation and rooting on myrtle.

\section{MATERIAL AND METHODS}

\subsection{Plant Material}

Myrtle, Myrtus communis L., genotype was used for in vitro micropropagation and rooting experiments. Plant material was obtained from a commercial seedling company in Adana, Turkey.

\subsubsection{Surface Sterilization}

Shoot tips were cut from donor plants and washed under tap water about $10 \mathrm{~min}$, dipped in $70 \%$ ethanol for $2 \mathrm{~min}$, and then immersed in $10 \%$ sodium hypochlorite solution (commercial bleach solution with $4.5 \%$ active chlorine, v/v, NaOCl; Domestos ${ }^{\circledR}$ ) with 1-2 drops of Tween-20 for 20 min. afterwards they were washed three times with sterile distilled water.

\subsection{Multiplication Medium}

MS [13], OM [14] and WPM [15] medium supplemented with $1 \mathrm{mg} \mathrm{l}^{-1}$ BAP (benzylaminopurine), $30 \mathrm{~g} \mathrm{l}^{-1}$ sucrose, $8 \mathrm{~g} \mathrm{l}^{-1}$ agar, pH 5.8 were prepared and autoclaved at $121^{\circ} \mathrm{C}$ for $15 \mathrm{~min}$. Shoot tips of $M$. communis were cultured and propagated on MS medium, and incubated in a growth chamber at $25 \pm 2{ }^{\circ} \mathrm{C}$ under cool white fluorescent light at $16 \mathrm{~h}$ photoperiod condition. At the end of the three subculture, micropropagation rate, average plant length $(\mathrm{cm})$, number of leaf, fresh weight $(\mathrm{g})$ and dry weight $(\mathrm{g})$ were recorded.

\subsection{Rooting Medium}

Shoots were transferred to MS, OM and WPM medium with same components with multiplication medium except BAP. For rooting $1 \mathrm{mg} \mathrm{l}^{-1}$ IBA were used. The cultures were maintained incubated in a growth chamber at $25{ }^{\circ} \mathrm{C}$ under cool white fluorescent light at $16 \mathrm{~h}$ photoperiod condition. Six weeks later rooting rate, numbers of roots, fresh weight $(\mathrm{g})$, dry weight $(\mathrm{g})$, length of roots and plants $(\mathrm{cm})$ were recorded.

\subsection{Acclimatization and Ex Vitro Conditions}

Plantlets with well-developed shoots and roots were removed from different media boxes and the roots were washed gently under running tap water and dipped in a solution containing $50 \%(\mathrm{w} / \mathrm{v})$ of a $2.5 \mathrm{~g} \mathrm{l}^{-1}$ fungicide (Captan 50WP, Fruit\&Ornamental, NY, USA) for 10-15 s and then transferred to plastic pots $(7 \mathrm{~cm} \times 7 \mathrm{~cm}$ width and length) containing autoclaved peat (Klasmann, KTS-1) and perlite $(1: 1, \mathrm{v} / \mathrm{v})$. The potted plants were placed in a greenhouse under natural light at $95-98 \%$ relative humidity and $22-24^{\circ} \mathrm{C}$.

\subsection{Experimental Design and Statistical Analysis}

All experiments were performed in a completely randomized design with three replicates. All quantitative data expressed as percentages were subjected to arcsine transformation. All data were expressed as means. Means were separated by analysis of variance and LSD (the least significant difference) test was performed to evaluate differences among media in myrtle. Data analysis was performed by using the JMP ${ }^{\circledR}$ software (SAS Institute, Cary, NC) ver. 8.00 and significance was considered at $\mathrm{P}<0.05$.

\section{RESULTS AND DISCUSSION}

\subsection{Micropropagation on Media}

Micropropagation opportunities of myrtle were investigated using different plant tissue culture media. The rate of micropropagation and plant length, numbers of leaf, fresh weight and dry weight were determined on WPM, MS and OM media supplemented with $1 \mathrm{mg} \mathrm{l}^{-1}$ BAP. All data coming from micropropagation studies were presented in Table 1 and Fig.1. 


\section{TABLE 1}

DATA OF MICROPROPAGATION ON DIFFERENT MEDIA

\begin{tabular}{|c|c|c|c|c|c|}
\hline Medium & Plant Length (cm) & $\begin{array}{c}\text { Multiplication } \\
\text { Coefficient }\end{array}$ & $\begin{array}{c}\text { Number of Leaf } \\
\text { per Plant }\end{array}$ & Fresh Weight (g) & Dry Weight (g) \\
\hline WPM & 3.40 & $6.75 a$ & 41.30 & $0.20 \mathrm{a}$ & $0.038 \mathrm{a}$ \\
\hline MS & 3.17 & $4.20 \mathrm{a}$ & 34.45 & $0.14 a b$ & $0.019 \mathrm{a}$ \\
\hline $\mathrm{OM}$ & 2.77 & $3.70 \mathrm{~b}$ & 31.90 & $0.07 \mathrm{~b}$ & $0.013 b$ \\
\hline
\end{tabular}

Based on the micropropagation results, WPM was detected to be the best medium on all criteria. Plant length and numbers of leaf was determined that there is no statistically a difference among the media. The highest multiplication coefficient was obtained from WPM with 6.75. MS and OM has lower multiplication coefficient compared to WPM.

Fresh and dry weight of plants on micropropagation was also determined. The best data of mass was obtained from WPM similar to multiplication coefficient.

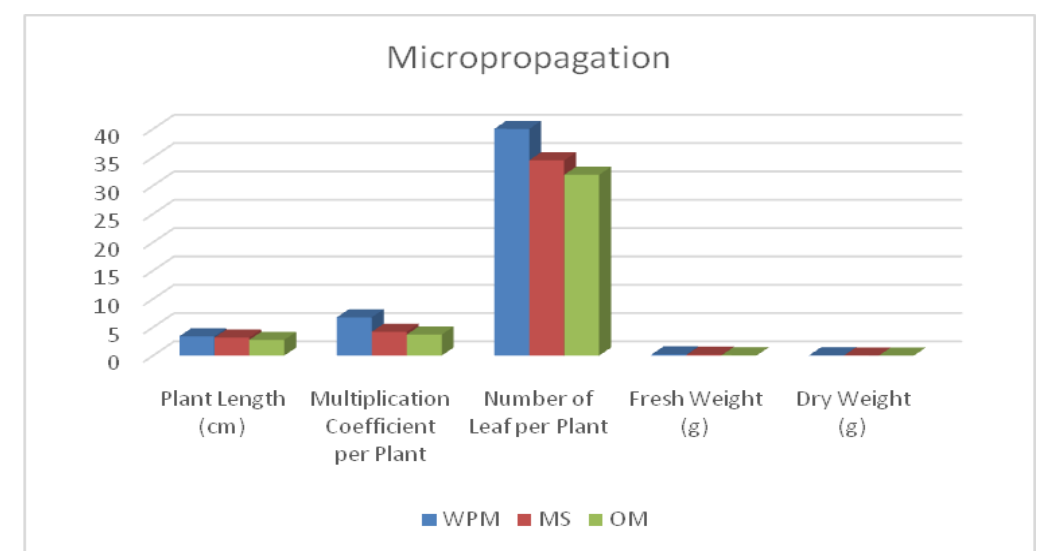

FIG. 1. ALL DATA COMING FROM MICROPROPAGATION STUDIES

Micropropagated myrtle plants on different media were showed in Fig. 2.

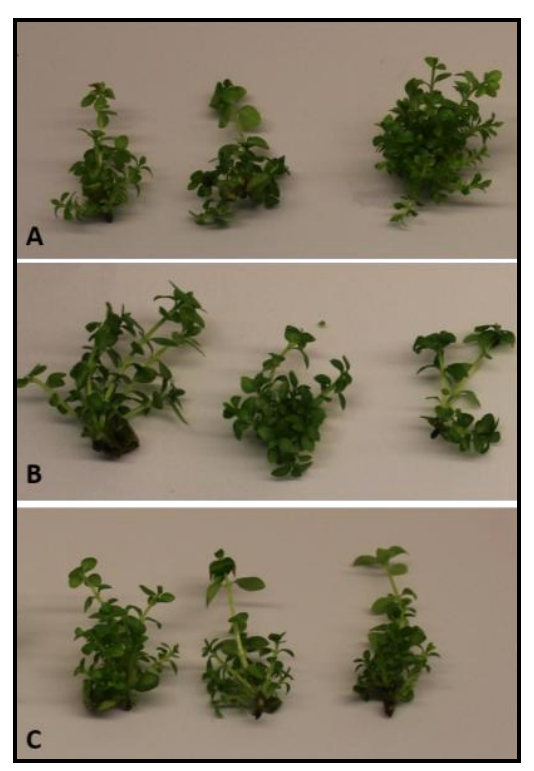

\section{Fig 2. MYRTLE PLANTS A. WPM, B. OM, C. MS}

Researchers have been used different nutrient media, plant growth regulators to optimize the micropropagation of myrtle plants in in vitro conditions for many years. Şan et al. [6] investigated the effects of different concentrations of TDZ (0.1, 0.3 and $\left.0.5 \mathrm{mg} \mathrm{l}^{-1}\right)$, BAP $\left(0.5,1.0\right.$ and $\left.2.0 \mathrm{mg} \mathrm{l}^{-1}\right)$ and NAA $\left(0.01\right.$ and $\left.0.1 \mathrm{mg} \mathrm{l}^{-1}\right)$ on shoot formation in myrtle clone 'Aşı Mersin'. They used MS medium as micropropagation medium. The most of the shoots were obtained MS medium containing $0.3 \mathrm{mg}$ 
$\mathrm{l}^{-1} \mathrm{TDZ}+0.1 \mathrm{mg} \mathrm{l}^{-1} \mathrm{NAA}$ in the $1^{\text {st }}$ subculture $(3.8$ shoot$)$, and from MS with $0.3 \mathrm{mg}^{-1} \mathrm{TDZ}+0.01 \mathrm{mg} 1^{-1} \mathrm{NAA}$ in the $2^{\text {nd }}$ subculture (4.0 shoot). In our study, the best micropropagation coefficient was calculated as 6.75 in WPM.

Rezaee and Kamali [10] investigated effect of different media and a different plant growth regulations and concentration of shoot proliferation in myrtle. The results indicated that between, MS and WPM, media, WPM showed better result rather than MS. In shoot proliferation stage were used BAP at levels of $0,0.5,1,2,3,4,5$ and $6 \mathrm{mg}^{-1}$ and IBA at levels of 0 and $0.1 \mathrm{mg} \mathrm{l}^{-1}$, then three traits containing: leaf number, shoot length, and shoot proliferation were examined. The best result was obtained by using of modified WPM medium with BAP in 4 and IBA in $0.1 \mathrm{mg} \mathrm{l}^{-1}$. In the present study, we also used $1 \mathrm{mg} \mathrm{l}^{-}$

${ }^{1} \mathrm{BAP}$ and we had positive results on multiplication rate.

Damiano et al. [16] carried out propagation studies in myrtle in order to find an efficient propagation protocol. MS medium with BAP $\left(0.6 \mathrm{mg} \mathrm{l}^{-1}\right)$, NAA $\left(0.01 \mathrm{mg} \mathrm{l}^{-1}\right)$ and $\mathrm{GA}_{3}\left(0.1 \mathrm{mg} \mathrm{l}^{-1}\right)$ was used for propagation of myrtle.

\subsection{Rooting on Media}

Rooting of myrtle was investigated in in vitro conditions using same plant tissue culture media with micropropagation. The rate of rooting and plant length, root length, numbers of root, numbers of leaf, fresh weight and dry weight were determined on WPM, MS and OM media supplemented with $1 \mathrm{mg} \mathrm{l}^{-1}$ IBA. All data coming from in vitro rooting studies were presented in Table 2 and Fig 3.

TABLE 2

DATA OF ROOTING ON DIFFERENT MEDIA

\begin{tabular}{|c|c|c|c|c|c|c|c|}
\hline Medium & $\begin{array}{c}\text { Rooting Rate } \\
(\%)\end{array}$ & $\begin{array}{c}\text { Plant Length } \\
(\mathbf{c m})\end{array}$ & $\begin{array}{c}\text { Root Length } \\
(\mathbf{c m})\end{array}$ & $\begin{array}{c}\text { Number of } \\
\text { Root per } \\
\text { Plant }\end{array}$ & $\begin{array}{c}\text { Number of } \\
\text { Leaf per } \\
\text { Plant }\end{array}$ & $\begin{array}{c}\text { Fresh } \\
\text { Weight (g) }\end{array}$ & $\begin{array}{c}\text { Dry Weight } \\
(\mathbf{g})\end{array}$ \\
\hline WPM & $100.00 \mathrm{a}(90.00)$ & 5.15 & $5.15 \mathrm{a}$ & 3.40 & 15.30 & $0.16 \mathrm{a}$ & $0.02 \mathrm{a}$ \\
\hline MS & $50.00 \mathrm{~b}(45.00)$ & 5.20 & $1.00 \mathrm{~b}$ & 0.80 & 15.80 & $0.06 \mathrm{~b}$ & $0.01 \mathrm{~b}$ \\
\hline OM & $70.00 \mathrm{ab}(72.00)$ & 6.80 & $4.30 \mathrm{a}$ & 2.10 & 16.90 & $0.11 \mathrm{ab}$ & $0.02 \mathrm{a}$ \\
\hline
\end{tabular}

$\mathrm{LSD}_{\text {RootingRate }}=32.18 * * \mathrm{LSD}_{\text {PlantLength }}=\mathrm{N} . \mathrm{S} . \mathrm{LSD}_{\text {RootLenght }}=1.86^{* * *} \mathrm{LSD}_{\text {NumberofRoot }}=\mathrm{N} . \mathrm{S} . \mathrm{LSD}_{\text {NumberofLeaf }}=$ N.S.

$\mathrm{LSD}_{\text {FreshWeight }}=0.06 * \mathrm{LSD}_{\text {DryWeight }}=0.01 *$

N.S.=Not Significant

$* \mathrm{P}<0.05$

$* *=\mathrm{P}<0.01$

$* * *=\mathrm{P}<0.001$

Values in parenthesis arcsine transformed

All plantlets on WPM were rooted. The second best medium was detected to be OM with $70 \%$. The lowest rooting rate (50\%) was calculated on MS medium. Comparing plant length among media, there is no any statistically differences. On the other hand, there is significant difference based on the root length. Plantlets coming from WPM has the best value with 5.15 $\mathrm{cm}$ per plant. WPM was also the best medium according to numbers of root per plant (3.40). The lowest root number was detected on MS medium with 0.80 . Fresh and dry weight of roots on rooting was also determined. The best data of mass was obtained from WPM.

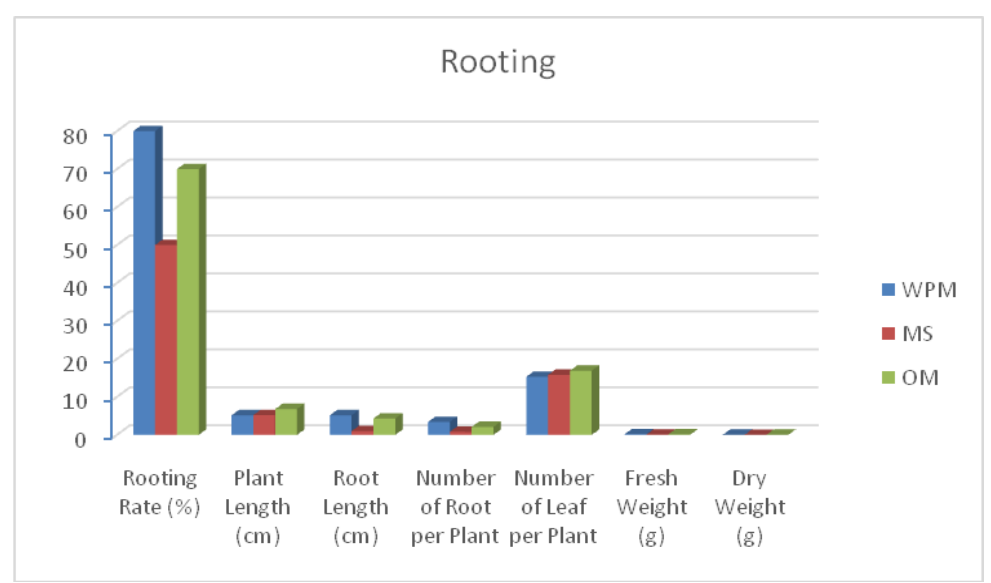

Fig 3. AlL DATA COMING FROM ROOTING STUDIES 
Rooted plants on different media were showed in Fig. 4.

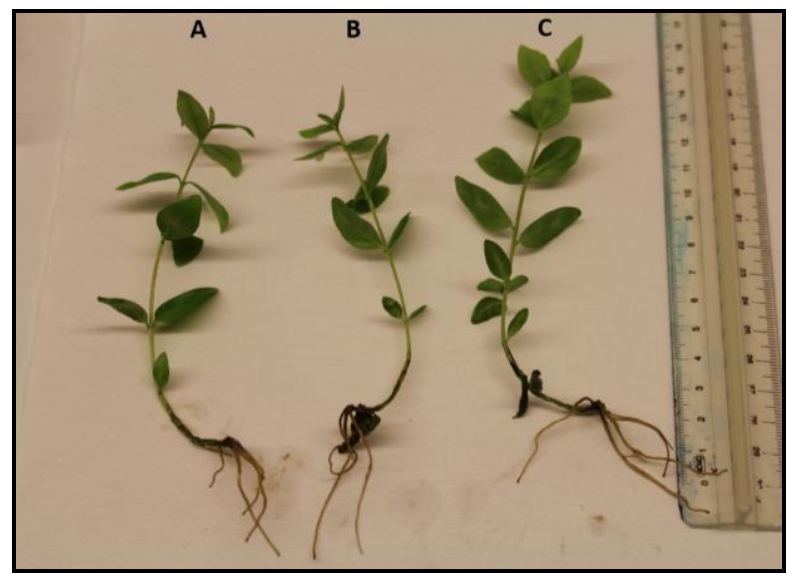

Fig 4. MYRTLE ROOTED PLANTS A. MS, B. OM, C. WPM

Activated Charcoal (AC) has been widely used in tissue culture studies. At the rooting stage, AC delays the disintegration of the auxin added into the medium and positively affects plant development by adsorbing the inhibitors such as phenolic substances and abscisic acid [17]. Şan et al. [6] in order to root the in vitro shoots, plantlets were cultured in $1 \frac{2}{2}$ MS medium containing $0,0.5,1.0,2.0$ and $4.0 \mathrm{mg} \mathrm{l}^{-1}$ IBA or NAA alone or in combination with $2.0 \mathrm{~g}^{-1}$ AC. IBA applications induced more rooting than NAA. The medium supplemented with $1.0 \mathrm{mg} \mathrm{l}^{-1} \mathrm{IBA}+2.0 \mathrm{~g} \mathrm{l}^{-1} \mathrm{AC}$ resulted in the highest rooting ratio $(80 \%)$. Addition of $\mathrm{AC}$ into the medium resulted in slight increase in the rooting ratio, significant increase in shoot length, and reduced darkening in the rooting area. In our study, high quality roots were obtained from all media. Different auxins can be used for rooting of plants in in vitro cultures. Auxins such as NAA, IBA, IAA routinely use for plant rooting in vitro cultures. Scarpa et al. [11] evaluated the influence of two IAA concentrations $\left(0.5 \mathrm{mg} \mathrm{l}^{-1}\right.$ and $\left.1 \mathrm{mg} \mathrm{l}^{-1}\right)$ and different medium to induce root induction of Myrtle. Researchers found that the best rooting results $(61 \%)$ were obtained with 013 medium containing 1 mg 1-1 IAA. Hatzilazarou et al. [12] investigated that rooting capability of two M. communis clones, with large (clone A) and small (clone B) leaves. Shoots transferred to WPM medium supplemented with various concentrations $(0,0.5$, 1 or $2 \mu \mathrm{M})$ of IBA, IAA or NAA in rooting assays. According to this study, the best rooting was achieved with the application of $0.5 \mu \mathrm{M}$ IBA (96\% rooting) and $1 \mu \mathrm{M}$ IAA (100\% rooting) for clone A and B, respectively. Ruffoni et al. [18] determined that IAA and IBA at $0.5 \mathrm{mg} \mathrm{l}^{-1}$ increased the rooting percentage and evidenced a difference in the shape and length of the roots in myrtle plant. Aka Kacar et al. [9] investigated the effects of different IBA $\left(0,1,2,4 \mathrm{mg} \mathrm{l}^{-1}\right)$ and AC $(0$, $0.5,1,2 \mathrm{~g} \mathrm{l}^{-1}$ ) concentrations on myrtle rooting in in vitro conditions. They used agar MS medium for rooting and reported that the best combination were detected $2 \mathrm{mg}^{-1} \mathrm{IBA}$ without $\mathrm{AC}$ in terms of rooting rate.

\subsection{Acclimatization}

Plantlets with shoots and roots from different media were transferred to plastic pots. Plants were successfully acclimatized in a greenhouse. There were no statistically differences among the treatments on survival. However, plants from WPM showed better performance on survival.

\section{CONCLUSION}

Many different biotechnological methods can be applied to plant to have better ones in the process of plant breeding. One of the widest applications of biotechnology has been in the area of plant tissue culture in fruit crops. Today plant tissue culture applications encompass much more than clonal propagation and micropropagation [19].

In conclusion, the WPM, OM and MS medium represent a valid in vitro micropropagation and rooting for the mass propagation. We showed that different media content could be used for myrtle micropropagation and rooting. Comparative investigations among different media that shoot proliferation, rooting and growth were more efficient in WPM.

\section{ACKNOWLEDGEMENTS}

This research was supported by Çukurova University, Scientific Research Project Unit (Project No: FBA-2015-4865). 


\section{REFERENCES}

[1] A. Bouzabata, C. Cabral, M. J. Gonçalves, M. T. Cruz, A. Bighelli, C. Cavaleiro, J. Casanova, F. Tomi, and L. Salgueiro, “Myrtus communis L. As Source of A Bioactive and Safe Essential Oil”, Food Chem Toxicol, vol. 75, pp. 166-172, 2015.

[2] C. Aydın, and M. M. Özcan, "Determination of Nutritional and Physical Properties of Myrtle (Myrtus communis L.) Fruits Growing Wild in Turkey", J Food Eng, vol. 79(2), pp. 453-458, 2007.

[3] B. Şan, A. N. Yildirim, M. Polat, and F. Yildirim, "Chemical Compositions of Myrtle (Myrtus communis L.) Genotypes Having Bluish-Black and Yellowish-White Fruits", Erwerbs-obstbau, vol. 57(4), pp. 203-210, 2015a.

[4] G. H. S. Bonjar, “Antibacterial Screening of Plants Used in Iranian Folkloric Medicine”, Fitoterapia, vol. 75, pp. 231-235, 2004.

[5] N. Hayder, A. Abdelwahed, S. Kilani, R. Ben Ammar, A. Mahmoud, K. Ghedira, and L. Chekir-Ghedira, "Anti-Genotoxic and FreeRadical Scavenging Activities of Extracts From (Tunisian) Myrtus communis", Mutat Res, vol. 564, pp. 89-95, 2004.

[6] B. Şan, Y. Karakurt, and F. Dönmez, "Effects of Thidiazuron and Activated Charcoal on In Vitro Shoot Proliferation and Rooting of Myrtle (Myrtus communis L.)", Tarım Bilimleri Dergisi, vol. 21(2), pp. 177-183, $2015 \mathrm{~b}$.

[7] S. Kordali, A. Usanmaz, A. Cakir, A. Komaki, and S. Ercisli, "Antifungal and Herbicidal Effects of Fruit Essential Oils of Four Myrtus communis Genotypes”, Chem Biodivers, vol. 13(1), pp. 77-84, 2016.

[8] A. Shahzad, S. Sharma, S. Parveen, T. Saeed, A. Shaheen, R. Akhtar, V. Yadav, A. Upadhyay, and Z. Ahmad, "Historical Perspective and Basic Principles of Plant Tissue Culture", In Plant Biotechnology: Principles and Applications, Springer Singapore, 2017, pp. 1-36.

[9] Y. Aka Kacar, Ö. Şimşek, B. Biçen, and B. Dal, “In Vitro Rooting of Micropropagated Shoots From Myrtus communis Linn: Influence of Activated Charcoal and Indole-3-Butyric Acid (IBA)", Acta Hort, 2017. 10.17660/ActaHortic.2017.1155.78.

[10] A. Rezaee, and K. Kamali, “A New Commercial Protocol for Micropropagation of Myrtus tree”, Adv Biores, vol. 5(4), pp. 73-79, 2014.

[11] G. M. Scarpa, M. Milia, M. Satta, "The Influence of Growth Regulators on Proliferation and Rooting of In vitro Propagated Myrtle", Plant Cell Tiss Org, vol. 62, pp. 175-179, 2000.

[12] S. Hatzilazarou, H. Grammatikos, A. S. Economou, N. Rifaki, and P. Ralli, "Rooting In Vitro and Acclimatization of Myrtus communis Microcuttings", Acta Hort (ISHS), vol. 616, pp. 259-264, 2001.

[13] T. Murashige, and F. Skoog, "A Revised Medium for Rapid Growth and Bioassays with Tobacco Tissue Cultures", Physiol Plantarum, vol. 15, pp. 473-497, 1962.

[14] E. Rugini, "In Vitro Propagation of Some Olive Cultivars with Different Root-Ability and Medium Development Using Analytical Data from Developing Shoots and Embryos", Sci Hortic, vol. 24, pp. 123-134, 1984.

[15] G. B. Lloyd, and B. H. McCown, "In: Proceedings of the International Plant Propagation Society”, vol. 30, pp. 421-421, 1980.

[16] C. Damiano, M. D. A. Padró, and A. Frattarelli, "Propagation and Establishment In Vitro of Myrtle (Myrtus communis L.), Pomegranate (Punica granatum L.) and Mulberry (Morus alba L.)”, Propag Ornam Plants, vol. 8(1), pp. 3-8, 2008.

[17] T. D. Thomas, "The Role of Activated Charcoal in Plant Tissue Culture", Biotechnol Adv, vol. 26(6), pp. 618-631, 2008.

[18] B. Ruffoni, C. Mascarello, and M. Savona, "In Vitro Propagation of Ornamental Myrtus (Myrtus communis)", In: J. Shri Mohan, O. Sergio J. (Eds.), Protocols for In Vitro Propagation of Ornamental Plants Methods in Molecular Biology, 2010, vol. 589, pp. 257269.

[19] D. Dönmez, Ö. Şimşek, and Y. Aka Kaçar, “Genetic Engineering Techniques in Fruit Science”, Int J Environ Agric Res (IJOEAR), vol. 2(12), pp. 115-128, 2016. 